Far Eastern Entomologist

\begin{tabular}{lll}
\hline Number 449: 9-17 & ISSN 1026-051X (print edition) & March 2022 \\
\hline
\end{tabular}

https://doi.org/10.25221/fee.449.2

http://zoobank.org/References/31027918-DC38-4FF8-8863-1657F936BB68

\title{
NEW TO THE FAUNA OF INDIA LADYBIRD BEETLES (COLEOPTERA: COCCINELLIDAE)
}

\author{
P. Das ${ }^{1, *)}$, G. K. Saha ${ }^{2)}$, K. Chandra ${ }^{1)}$, D. Gupta ${ }^{1)}$
}

1) Zoological Survey of India, M Block, New Alipore, 700053 Kolkata, West Bengal, India. *Corresponding author, E-mail: priyankajan03@gmail.com

2) Department of Zoology, University of Calcutta, 35 Ballygunge Circular Road, 700019 Kolkata, India.

Summary. Aspidimerus birmanicus (Gorham, 1895), Cryptogonus nepalensis bhutanensis Bielawski, 1979, Henosepilachna processa Li et Cook, 1961, Sticholotis punctata Crotch, 1874, and Synona consanguinea Poorani Ślipiński et Booth, 2008 are reported for the first time from India. The diagnosis, illustrations and the map of distribution of these species are also provided.

Key words: Coccinellinae, Aspidimerini, Coccinellini, Epilachnini, Sticholotidini, distribution, fauna, new records, Northeast India.

П. Дас, Г. К. Саха, К. Чандра, Д. Гупта. Новые для фауны Индии божьи коровки (Coleoptera: Coccinellidae) // Дальневосточный энтомолог. 2022. N 449. C. 9-17.

Резюме. Впервые для фауны Индии указываются Aspidimerus birmanicus (Gorham, 1895), Cryptogonus nepalensis bhutanensis Bielawski, 1979, Henosepilachna processa Li et Cook, 1961, Sticholotis punctata Crotch, 1874 и Synona consanguinea Poorani Ślipiński et Booth, 2008. Для всех видов также приведены диагнозы, иллюстрации и карты-схемы распространения.

\section{INTRODUCTION}

The ladybird beetles belonging to family Coccinellidae, globally comprise over 6,000 species (Robertson et al., 2015), of them nearly 550 species are recorded from India (Poorani, 2019), that is only $9.1 \%$ of the global diversity. Ladybird beetles being directly associated with many plants (considering the phytophagous tribe Epilachnini) and their associated pests (aphids, mites, scale insects etc.) is expected to procure more number of species. This biologically important group is often misidentified because of cryptic variations. Herein, five species of subfamily Coccinellinae in four tribes are reported from India for the first time with illustrations and remarks on their distribution.

\section{MATERIAL AND METHODS}

Specimens examined were deposited at National Zoological Collection of Zoological Survey of India, Kolkata NZSI]. These specimens were examined using a Nikon SMZ25 
stereo zoom-microscope, and the photos were taken using DS-Ri2 camera attached with it, and they were processed with NIS Elements BR 5.10.00 imaging software. Minor image corrections were conducted using Adobe Photoshop 7 software. Kolkata.

\section{NEW RECORDS}

Subfamily Coccinellinae Latreille, 1807

Tribe Aspidimerini Mulsant, 1850

Genus Aspidimerus Mulsant, 1850

REMARKS. So far, a single species of this genus (A. spencei Mulsant, 1850) was recorded from Assam and Meghalaya in India (Poorani, 2002).

\section{Aspidimerus birmanicus (Gorham, 1895)}

Figs 1-7

Cryptogonus birmanicus Gorham, 1895: 691.

Aspidimerus birmanicus: Kapur, 1948: 84, figs. 4A (habitus, male), 4B (male genitalia), 4C

(siphonal capsule); Poorani, 2002: 343 (checklist); Huo et al., 2013: 71 (checklist).

MATERIAL EXAMINED. India: Assam, Kaziranga, V.1961, 1q, coll. G. Scherer [NZSI].

DIAGNOSIS. Body length 3.8-5.0 mm, width 2.8-3.8 mm. Body elongate-oval; head reddish brown, finely punctate in females; pronotum black (brown in females) excluding anterolateral margins; scutellum black; elytra black (reddish brown in females) with two subrounded spots on disc, more or less extended up to lateral margin, located near apex base; ventrites black to dark brown; legs and abdominal sternites reddish brown.

DISTRIBUTION. India (new record), Myanmar (Kapur, 1948) and Thailand (Huo et al., 2013).

REMARKS. Kapur (1948) illustrated the male habitus, male genitalia and siphonal capsule based on the specimens from Mongphu and Maymyo (Myanmar). A. birmanicus can be distinguished from closely related species by the following characters: the colour of elytra black with two spots, dorsum moderately convex and densely pubescent, penis relatively long, curved almost in a circle in the whole length. Penis guide symmetrical with apex arcuate or truncate in ventral view (Huo et al., 2013). Here A. birmanicus is reported for the first time from India, based on the female specimen. The female habitus, antennae, labium, mandible, maxilla and maxillary palpi are illustrated for the first time.

\section{Genus Cryptogonus Mulsant, 1850}

REMARKS. The fauna of India consists of 14 species (Kapur, 1948; Poorani, 2002, 2019)

Cryptogonus nepalensis bhutanensis Bielawski, 1979

Figs 8-13

Cryptogonus nepalensis bhutanensis Bielawski, 1979: 109, fig. 96; Poorani, 2002: 345

(checklist); Huo et al., 2015: 209; Dorji et al., 2019: 502 (checklist).

MATERIAL EXAMINED. India: Meghalaya, Jaintia Hills, Jawai, 20.IX 1988, $2 \hat{\jmath}, 3$, coll. V.D. Srivastava [NZSI]. 
DIAGNOSIS. Body length: $2.3-2.5 \mathrm{~mm}$, width: $1.7-2.0 \mathrm{~mm}$. Body round, convex; head yellow, finely punctate in males and coarsely punctate in females, pubescent; pronotum black, anterior margins yellow; scutellum black; elytra yellowish brown, first black spot subrounded on lateral half, a second spot located parallel with first on suture, joined to form a complete round, third spot smaller that others on posterior half of elytron; ventrite black; legs brownish.

DISTRIBUTION. India (new record), Bhutan and China (Bielawski, 1979; Huo et al., 2015; Dorji et al., 2019).

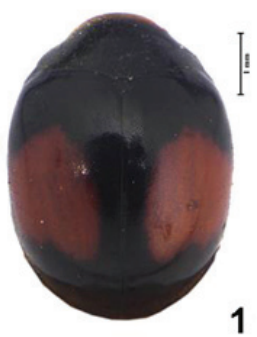

1

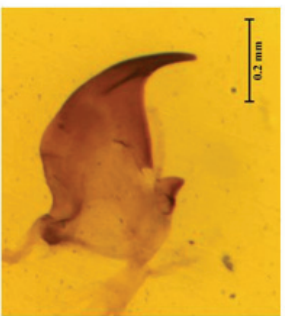

4

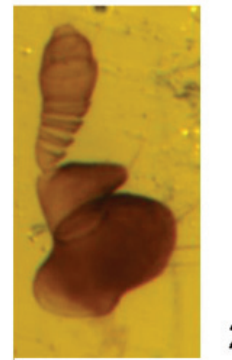

2
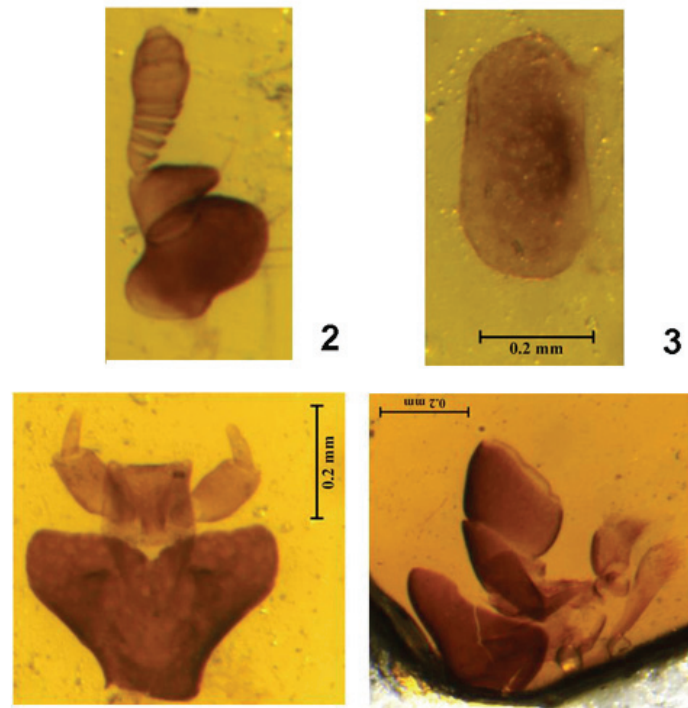

5

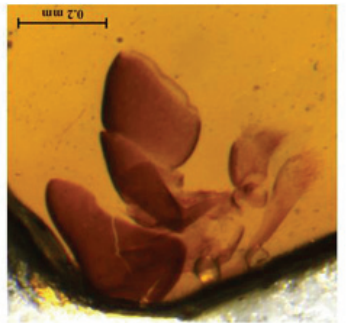

6

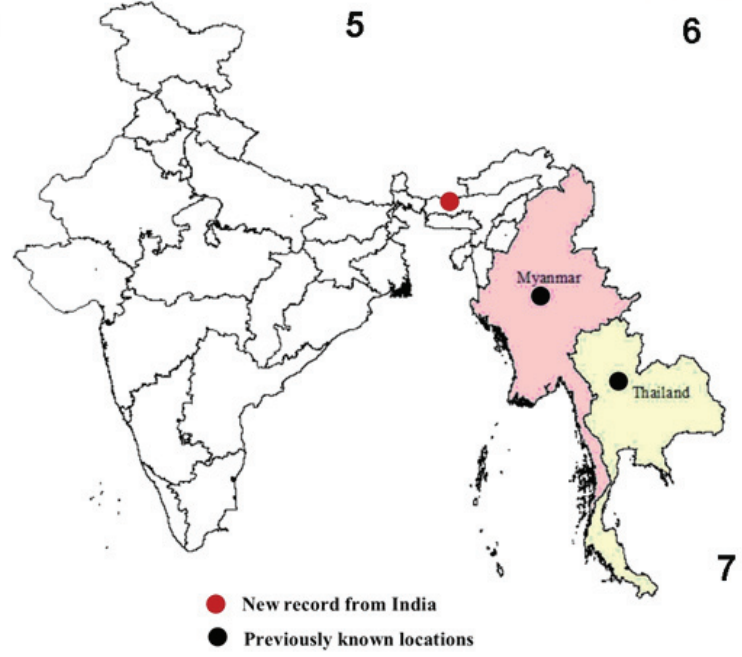

Figs 1-7. Aspidimerus birmanicus. 1 - habitus, dorsal view; 2 - antennae; 3 - labium; 4 - mandible; 6 - maxilla; 6 - maxillary palpi; 7 - distribution map. 
REMARKS. Bielawski (1979) characterized this subspecies by follow: head yellowish, pronotum and scutellum black, base and apex of elytron rather widely black with two large black spots on each elytron and one spot common to both. C. nepalensis bhutanensis in colour pattern and male copulatory apparatus are almost identical with the nominotypical subspecies, but can be distinguished from latter by fissures at the end of the penis marked feebly (Bielawski, 1972: figs. 53, 61). The male genitalia of our specimens (Figs 10-12) are identical to the description given by Bielawski (1979).

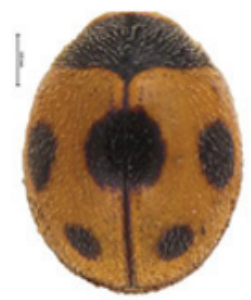

8
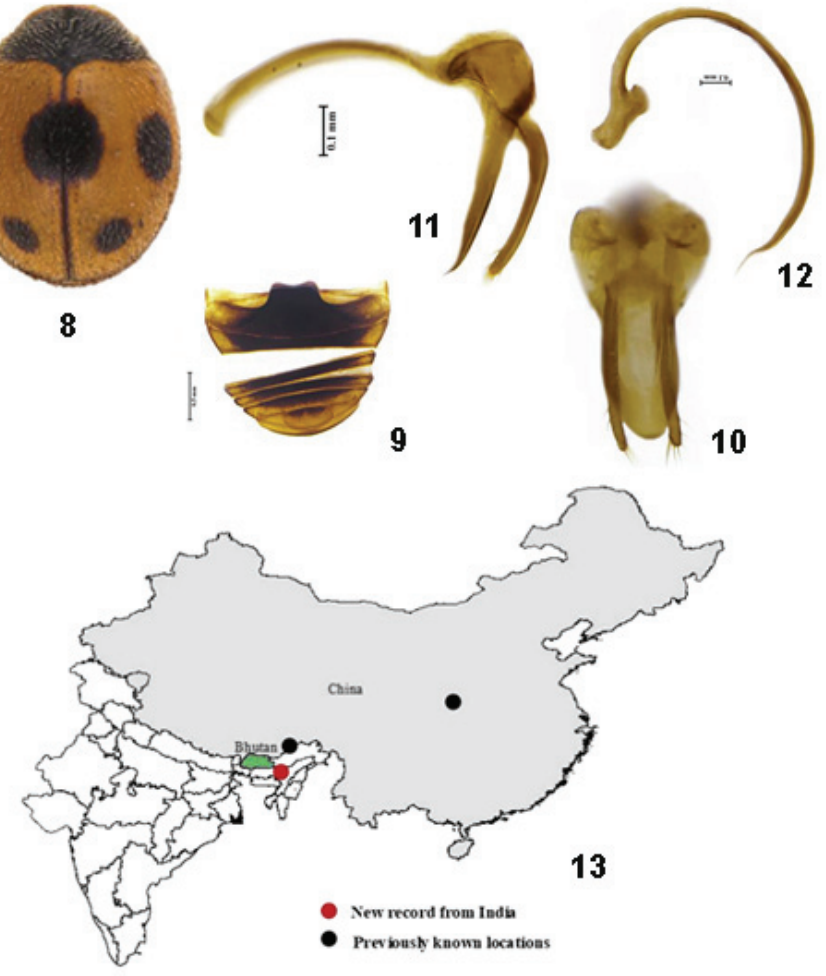

Figs 8-13. Cryptogonus nepalensis bhutanensis. 8 - habitus, dorsal view; 9 - abdomen; 10 - tegmen, inner; 11 - tegmen, lateral; 12 - penis; 13 - distribution map.

\section{Tribe Coccinellini Latreille, 1807}

Genus Synona Pope, 1989

REMARKS. The genus includes 3 species from India (Poorani, 2002; Poorani et al., 2008).

\section{Synona consanguinea Poorani, Ślipiński et Booth, 2008}

Figs 14-19

Synona consanguinea Poorani et al., 2008: 592, figs. 5-6 (habitus), 43-50 (male genitalia), 55-56 (female genitalia). 
MATERIAL EXAMINED. India: Tripura, West Tripura, Ishanchandra Nagar, 28.III 2018, $1 \hat{\jmath}, 1$, , coll. Priyanka Das [NZSI].

DIAGNOSIS. Body length: $4.9-5.1 \mathrm{~mm}$, width: $4.9-5.0 \mathrm{~mm}$. Body elongate oval to round, convex, glabrous; pronotum yellow-orange; scutellum yellow; elytra black; ventrite pale orange yellow; epipleura black.

DISTRIBUTION. India (new record), China (including Taiwan), Myanmar, Thailand, and Vietnam (Poorani et al., 2008).

REMARKS. Our specimens are identical to the description and illustrations provided by Poorani et al. (2008).
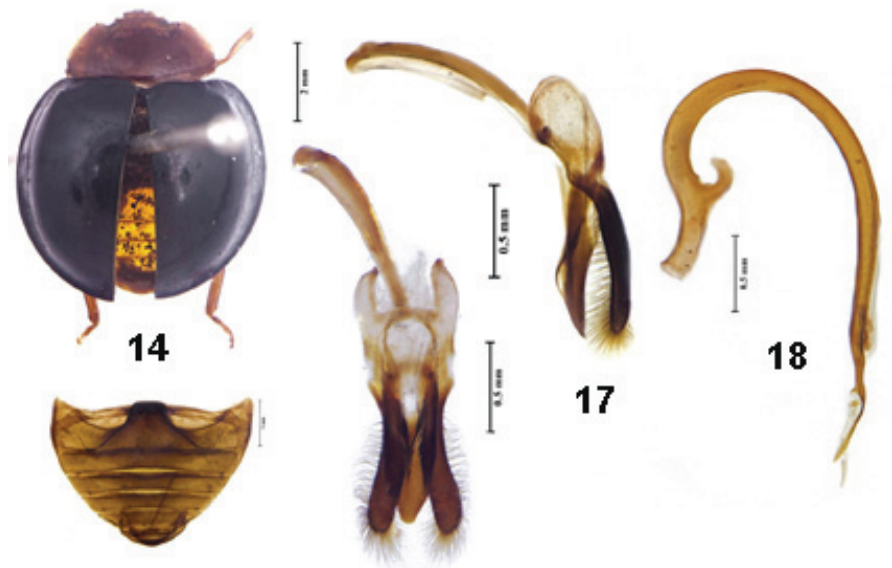

15

16

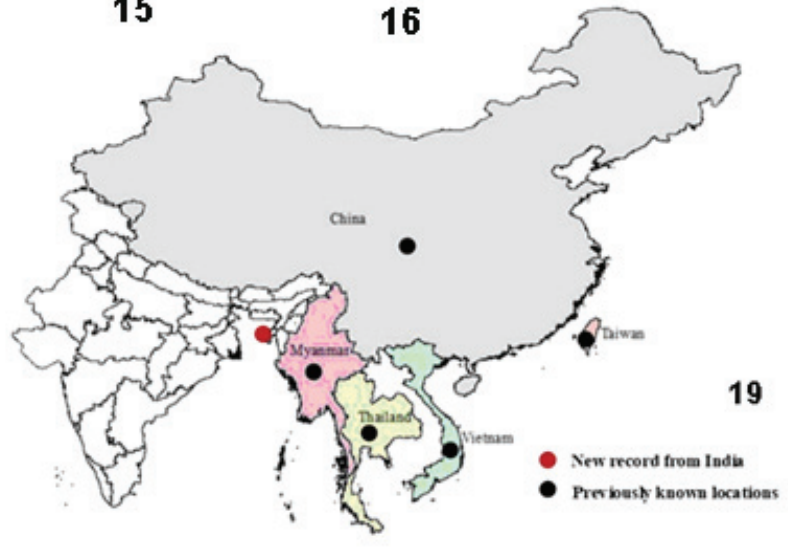

Figs 14-19. Synona consanguinea. 14 - habitus, dorsal view; 15 - abdomen; 16 - tegmen, inner; 17 - tegmen, lateral; 18 - penis; 19 - distribution map.

\section{Tribe Epilachnini Mulsant, 1846}

Genus Henosepilachna Li, 1961

REMARKS. There are 24 species of this genus recorded from India (Poorani, 2004). 


\section{Henosepilachna processa $\mathrm{Li}$ et Cook, 1961}

Figs 20-25

Henosepilachna processa Li \& Cook 1961: 45, figs. 2 (abdominal sternite), 15-16 (elytra), 30-32 (male genitalia), 49-50 (abdominal tergite in dorsal and ventral view), 51 (female genitalia in ventral view); Dorji et al., 2019: 518 (checklist).

MATERIAL EXAMINED. India: Mizoram, Aizawl, University Campus, 28.III 2018, 20, coll. Priyanka Das (25702/H4A) [NZSI]; Nagaland, Zuheboto, Maromi, 22.VII 1991, $1 \hat{\jmath}, 2$, , coll. Y.P. Sinha (26048/H4A) [NZSI].

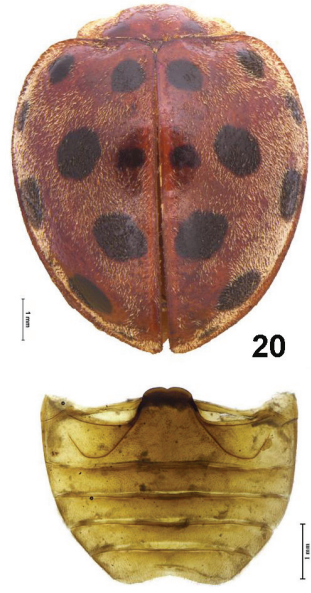

21

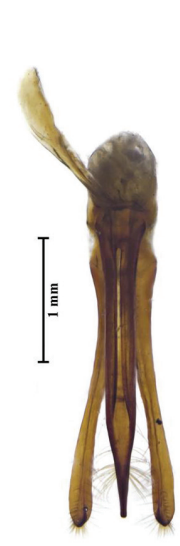

22

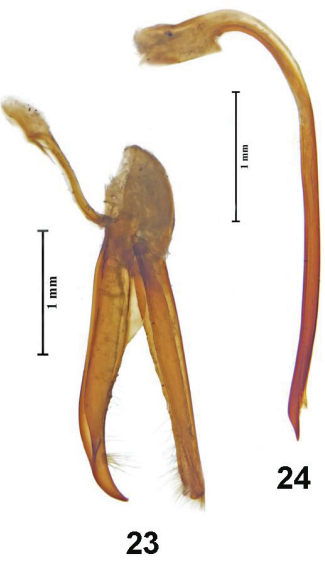

23

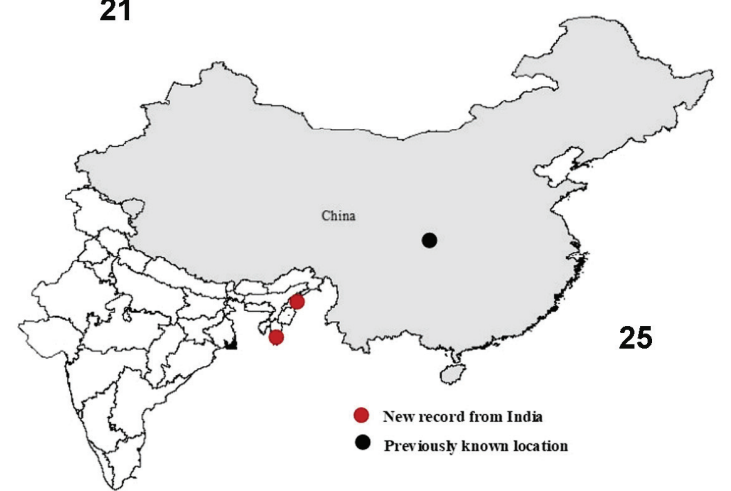

Figs 20-25. Henosepilachna procera. 20 - habitus, dorsal view; 21 - abdomen; 22 tegmen, inner; 23 - tegmen, lateral; 24 - penis; 25 - distribution map.

DIAGNOSIS. Body length: 8.5-9.0 mm; width: 7.3-7.7 mm. Body oval, convex, pubescent; antennae $0.5-1.0$ of head width; pronotum black with edges dark yellow; scutellum reddish brown; Elytra dark orange to reddish brown, with black maculae; hypomeron finely punctate; prosternum without carinae; metaventral postcoxal lines joined or almost so on metaventral process in somewhat W-shaped line in middle; tibial spurs: 1-2-2; tegminal basal piece with a pair of spines on inner margin near base of tegminal strut. 
DISTRIBUTION. India (new record), Bhutan (Dorji et al., 2019), China (Li \& Cook, 1961).

\section{Tribe Sticholotidini Weise, 1901 \\ Genus Sticholotis Crotch, 1874}

REMARKS. The genus includes 21 species from India (Poorani, 2002).

\section{Sticholotis punctata Crotch, 1874}

Figs 26-29

Sticholotis punctata Crotch, 1874: 201; Mader, 1955: 820-821, fig. 10; Sasaji, 1971: 73; Ren et al., 2009: 34; Wang et al., 2017, 25 figs. 1-10 (body parts), 59-61 (habitus), 197-200 (male genitalia), 299 (distribution map).

Sticholotis rufosignata Weise, 1885: 239.

MATERIAL EXAMINED. India: Meghalaya, Shillong, Cherrapunji, 24.XII 1958, 1ठ, col. A.P. Kapur [NZSI].

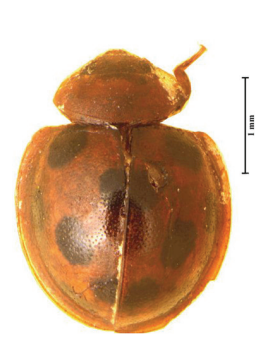

26

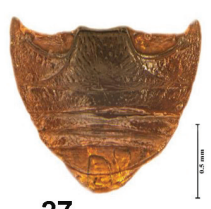

27
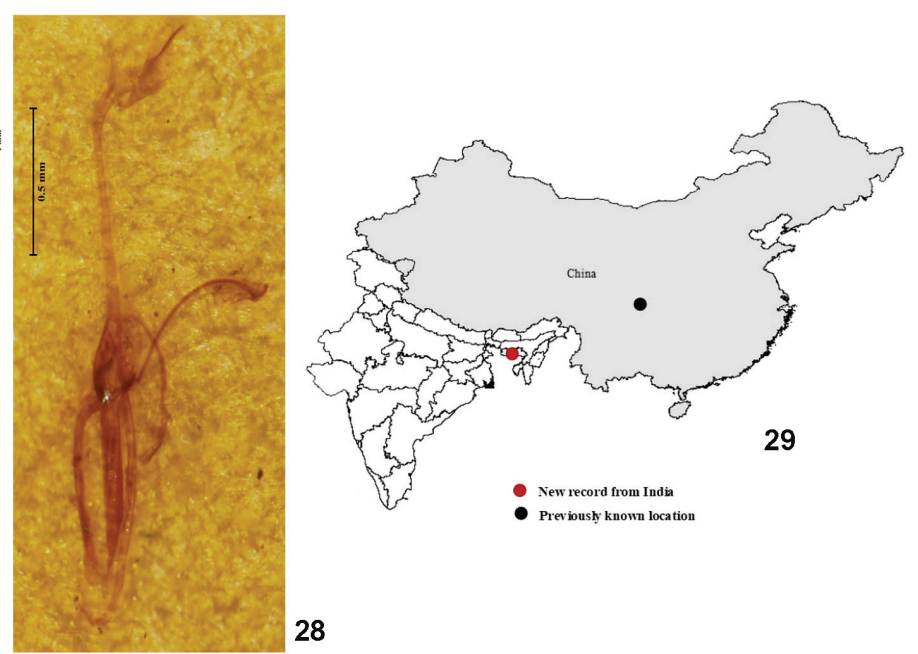

Figs 26-29. Sticholotis punctata. 26 - habitus, dorsal view; 27 - abdomen; 28 - tegmen and penis; 29 - distribution in India and China.

DIAGNOSIS. Body length: $2.1-2.5 \mathrm{~mm}$; width: $1.7-2.0 \mathrm{~mm}$. Body nearly round, hemispherical, strongly convex, glabrous; head dark yellow; pronotum black with edges dark yellow; scutellum reddish brown; elytral dark yellow to reddish brown, margins wide, visible from above, 6 large black rounded spots, first pair on the humeral calli reaching basal margin, second pair on disc slightly posteriad of half length of elytron, third largest on $2 / 5$ length of elytral suture; fourth just before sutural apex; underside dark brown, with elytral epipleuron and legs yellow.

DISTRIBUTION. India (new record), China, Japan, Malaysia, the Philippines (Ren et al., 2009; Wang et al., 2017). 


\section{ACKNOWLEDGMENTS}

We are grateful to the Director, Zoological Survey of India for all the support. The authors are gratified to Dr Karol Szawaryn (Museum and Institute of Zoology, Polish Academy of Sciences, Warszawa, Poland) for his support in the literature. We also wish to thank Dr Xingmin Wang (South China Agricultural University, Guangzhou, China) for his help in providing literature. The paper is a part of $\mathrm{PhD}$ work by the first author.

\section{REFERENCES}

Bielawski, R. 1972. Die Marienkäfer (Coleoptera: Coccinellidae) aus Nepal. Fragmenta Faunistica, 18: 283-312.

Bielawski, R. 1979. Ergebnisse der Bhutan-Expedition 1972 des Naturhistorischen Museums in Basel. Coleoptera: Fam. Coccinellidae. Entomologica Basiliensia, 4: 83-125.

Crotch, G.R. 1874. A Revision of the Coleopterous Family Coccinellidae. Cambridge, University Press, London. $311 \mathrm{pp}$.

Dorji, C., Loday, P. \& Vorst, O. 2019. A preliminary checklist of the Coccinellidae of Bhutan (Insecta: Coleoptera). Zootaxa, 4712(5): 497-530. DOI: 10.11646/zootaxa. 4712.4.2

Gorham, H.S. 1895. On the Coccinellidae collected by Mr. L. Fea in Burma. Annali del Museo Civico di Storia Naturale (Genova), 34(2): 683-695.

Huo, L., Wang, X., Chen, X. \& Ren, S. 2013. The genus Aspidimerus Mulsant, 1850 (Coleoptera, Coccinellidae) from China, with descriptions of two new species. ZooKeys, 348: 47-75. DOI: 10.3897/zookeys.348.5746

Huo, L., Li, W., Chen, X., Ren, S. \& Wang, X. 2015. New species, new synonymies and a new record of the genus Cryptogonus Mulsant, 1850 (Coleoptera, Coccinellidae) from China. Deutsche Entomologische Zeitschrift, 62(2): 203-210. DOI: 10.3897/dez.62.5242

Kapur, A.P. 1948. A revision of the tribe Aspidimerini Weise (Coleoptera: Coccinellidae). Transactions of the Royal Entomological Society of London, 99: 77-128.

Li, C.S. \& Cook, E.F. 1961. The Epilachninae of Taiwan (Col.: Coccinellidae). Pacific Insects, 3(1): 31-91.

Mader, L. 1955. Evidenz der paläarktischen Coccinelliden und ihrer Aberrationen in Wort und Bild. 2. Entomologische Arbeiten aus dem Museum G. Frey Tutzing bei Muenchen, 6: $765-1035$

Poorani, J. 2002. An annotated checklist of the Coccinellidae (Coleoptera) (excluding Epilachninae) of the Indian subregion. Oriental Insects, 36: 307-383.

Poorani, J. 2004. An Annotated Checklist of the Coccinellidae (Coleoptera) of Indian Subregion. 1-90. Available from: http://www.angelfire.com/bug2/j_poorani/

Poorani, J. 2019. 14. Coccinellidae of the Indian Subcontinent. P. 223-246. In: Ramani S., Mohanraj P., Yeshwanth H.M. (Eds). Indian Insects: Diversity and Science. CRC Press, Taylor and Francis.

Poorani, J., Ślipiński, A. \& Booth, R.G. 2008. A revision of the genus Synona Pope, 1989 (Coleoptera: Coccinellidae: Coccinellini). Annales Zoologici, 58(3): 579-594.

Ren, S., Wang, X., Pang, H., Peng, Z. \& Zeng, P. 2009. Colored Pictorial Handbook of Ladybird Beetles in China. Science Press, Beijing. 336 pp. [In Chinese]

Robertson, J.A., Ślipiński, A., Moulton, M., Shockley, F.W., Giorgi, A., Lord, N.P., Mckenna, D.D., Tomaszewska, W., Forrester, J., Miller, K.B., Whiting, M.F. \& Mchugh, J.V. 2015. Phylogeny and classification of Cucujoidea and the recognition of a new superfamily Coccinelloidea (Coleoptera: Cucujiformia). Systematic Entomology, 40: 745-778. 
Sasaji, H. 1971. Fauna Japonica. Coccinellidae (Insecta: Coleoptera). Academic Press of Japan. 340 pp.

Wang, X., Escalona, H.E., Ren, S. \& Xiaosheng, C. 2017. Taxonomic review of the ladybird genus Sticholotis from China (Coleoptera: Coccinellidae). Zootaxa, 4326(1): 001-072. 